GRASAS Y ACEITES 69 (4)

October-December 2018, e282

ISSN-L: 0017-3495

https://doi.org/10.3989/gya.0229181

\title{
Improving the chemical properties of Buriti oil (Mauritia flexuosa L.) by enzymatic interesterification
}

\author{
P. Speranza ${ }^{\mathrm{a}, \bowtie}$, K.M.M. Leão ${ }^{\mathrm{a}}$, T.S. Narciso Gomes ${ }^{\mathrm{a}}$, L.V.C Reis ${ }^{\mathrm{a}}$, A.P. Rodrigues ${ }^{\mathrm{c}}$, \\ J. Alves Macedo ${ }^{a}$, A.P.B. Ribeiro ${ }^{\mathrm{b}}$ and G. Alves Macedo, ${ }^{\mathrm{a},}$ \\ ${ }^{a}$ Faculty of Food Engineering, Department of Food and Nutrition, \\ University of Campinas, 80, Monteiro Lobato ST., 13083-970, Campinas, SP, Brazil. \\ ${ }^{\mathrm{b}}$ Faculty of Food Engineering, Department of Food Technology, University of Campinas \\ ${ }^{c}$ Faculty of Food Engineering, Department of Food Science, University of Campinas \\ ${ }^{\square}$ Corresponding author: paulasperanza09@gmail.com; macedoga@gmail.com
}

Submitted: 23 February 2018; Accepted: 21 June 2018

SUMMARY: Although Amazonian oils present great potential for various applications, they have not been extensively explored for commercial use. In this study, the effects of enzymatic interesterification of buriti oil in relation to its triacylglycerol composition, regiospecific distribution of fatty acids, and minority compounds were evaluated. The results indicated that the lipase used in the reaction showed higher specificity for oleic acid and the sn- 1 and sn-3 positions of triacylglycerol, generating more unsaturated structured lipids. There were increases of $11 \%$ and $12.5 \%$ in unsaturated-unsaturated-unsaturated triacylglycerol types and reductions of $12.1 \%$ and $16.2 \%$ in saturated-unsaturated-unsaturated triacylglycerol types after 6 and 24 hours of reaction, respectively. At $24 \mathrm{~h}$ of reaction, the structured lipid formed was totally unsaturated at the three triacylglycerol positions. In addition, as the reaction conditions were mild, the carotenoids and phenolic compounds were maintained in the structured lipids. The results indicate that the enzymatic interesterification can be an alternative to produce structured lipids with new functionalities, and diversify the application of this oil from the Amazon.

KEYWORDS: $\beta$-carotene; Lipid class; Minor compounds; TAG; Tocopherols; Vegetal oils

RESUMEN: Mejora de las propiedades químicas del aceite de Buriti (Mauritia flexuosa L.) por interesterificación enzimática. Aunque los aceites amazónicos presentan un gran potencial de aplicación, están poco explorados comercialmente. En este estudio, se evaluaron los efectos de la interesterificación enzimática del aceite de Buriti en relación con la composición en triacilglicerol, la distribución regioespecífica de ácidos grasos y compuestos minoritarios. Los resultados indicaron que la lipasa usada en la reacción mostró una mayor especificidad para el ácido oleico y las posiciones sn-1 y sn-3 del triacilglicerol, generando más lípidos estructurados insaturados. Hubo un aumento entre 11,0\% - 12,5\% en el tipo de triacilgliceroles insaturados-insaturados-insaturados y una reducción de $12,1 \%$ - 16,2\% en los triacilgliceroles saturados-insaturados-insaturados después de 6 y 24 horas de reacción, respectivamente. A las 24 h de reacción, el lípido estructurado formado estaba totalmente insaturado en las tres posiciones del triacilglicerol. Además, como las condiciones de reacción fueron suaves, los compuestos carotenoides y fenólicos se conservaron en los lípidos estructurados. Los resultados indicaron que la interesterificación enzimática puede ser una alternativa para producir lípidos estructurados con nuevas funcionalidades, diversificando la aplicación de este aceite del Amazonas.

PALABRAS CLAVE: Aceites vegetales; $\beta$-caroteno; Clases de lípidos; Compuestos menores; TAG; Tocoferoles

ORCID ID: Speranza P https://orcid.org/0000-0003-4403-3720, Leão KMM https://orcid.org/0000-0003-0750-8432, Gomes TSN https://orcid.org/0000-0003-1108-4476, Reis LVC https://orcid.org/0000-0003-3819-8393, Rodrigues AP https://orcid.org/0000-0003-1654-9973, Macedo JA https://orcid.org/0000-0001-7504-8111, Ribeiro APB https://orcid. org/0000-0002-6532-1265, Macedo GA https://orcid.org/0000-0001-5255-2243

Citation/Cómo citar este artículo: Speranza P, Leão KMM, Gomes TSN, Reis LVC, Rodrigues AP, Macedo JA, Ribeiro APB, Macedo GA. 2018. Improving chemical properties of Buriti oil (Mauritia flexuosa L.) by enzymatic interesterification. Grasas Aceites 69 (4), e282. https://doi.org/10.3989/gya.0229181

Copyright: (C2018 CSIC. This is an open-access article distributed under the terms of the Creative Commons Attribution 4.0 International (CC BY 4.0) License. 


\section{INTRODUCTION}

Buriti is a palm tree (Mauritia flexuosa L.), which dominates expansive areas and covers almost all of central Brazil and the lowlands of southern Amazonia. The oil extracted from this palm is used by local populations in frying and applied to skin to treat sunburns, to aid in skin healing, to treat snake and scorpion bites and to treat asthma (Morais and Gutjahr, 2011). In the literature, buriti oil has several beneficial properties, such as antimicrobial, antioxidant and antithrombotic actions (Speranza et al., 2016b; Siqueira et al., 2014).

The biological characteristics of buriti oil are mainly related to its minor compounds, in particular carotenoids, known for their positive health effects. The oil is one of the largest known sources of carotenoids (Rodriguez-Amaya et al., 2008). However, despite the potential for the application of buriti oil in cosmetic, food and pharmaceutical industries, its use is still quite limited. Few industries use it in their formulations.

One of the alternatives for altering the functionality of fats in order to increase their application without substantially altering their contents in minor compounds is enzymatic interesterification. The use of lipases in these reactions allows the redistribution of fatty acids in triacylglycerol, changing the functionalities of fats. Several studies in the literature have demonstrated the effects of enzymatic interesterification on oils and fats (Speranza et al., 2015; Speranza et al., 2016a). Moreover, as lipases act under mild conditions of temperature and pressure, the minor compounds are preserved during the reaction (Speranza and Macedo, 2012; Reshma et al., 2008).

The purpose of this study was to evaluate the effect of the enzymatic interesterification of buriti oil on its new chemical composition. The change in the fatty acid distribution in triacylglycerol and the content of the minor buriti oil compounds interfere with the properties of lubrication, mechanical performance, structuring and nutritional properties. In this way, new applications can be developed for buriti oil, such as for the production of new moisturizers and sunscreens in the cosmetics industry, for the production of natural dyes for the food industry and as antimicrobial agent.

\section{MATERIALS AND METHODS}

Crude buriti oil was purchased from Beraca Sabará (São Paulo, Brazil). Commercial, purified and immobilized lipase from T. lanuginosa (Lipozyme TL-IM) was kindly supplied by Novozymes Latin America Ltda. All other reagents and solvents were of analytical grade.

\subsection{Fatty acids composition}

Fatty acids methyl esters were prepared according to the Hartman and Lago's method. A Shimadzu GCMS-QP2010S equipped with a flame ionization detector was used. A capillary chromatographic column $(60 \mathrm{~m}, 0.25 \mathrm{~mm}$ id with $0.25 \mu \mathrm{m}$ film thickness) was used to analyze the fatty acid methyl esters. The analysis was performed according to the methodology described by Basso et al. (2012). The analyses were carried out in duplicate and the mean \pm standard deviation was calculated for each sample.

\subsection{Enzymatic interesterification}

The enzymatic interesterification reaction was performed according to the methodology previously developed in our laboratory (Speranza et al., 2016a). The reaction was carried out in an orbital-shaking water bath at $150 \mathrm{rpm}$ for 6,14 and $24 \mathrm{~h}$ at $40{ }^{\circ} \mathrm{C}$ under vacuum at $40^{\circ} \mathrm{C}$, using $2.5 \%$ (w / w) of commercial lipase Lipozyme TL-IM (Novozymes). After completion of the reaction, the structured lipid was immediately filtered using a $0.45 \mathrm{~m}$ membrane filter and frozen. The activity of the enzyme was determined using olive oil as a substrate.

\subsection{Lipid classes}

The free fatty acids and partial glycerides of buriti oil and structured lipids were identified using high performance size exclusion chromatography (HPSEC) according to the methodology described by Guedes et al., (2014). The qualitative composition was determined by comparison of the retention times of the peaks with the respective standards of free fatty acids and glycerides. The analysis was performed in duplicate. The free fatty acids (FFA), monoacylglycerols (MAG) and diacylglycerols (DAG) were removed according to the Farmani et al., (2006) methodology. The oils were frozen at $-18{ }^{\circ} \mathrm{C}$ in the presence of nitrogen for later analysis.

\subsection{Regiospecific distribution}

The quantitative high-resolution ${ }^{13} \mathrm{C}$-nuclear magnetic resonance (NMR) spectroscopic method $\left({ }^{13} \mathrm{CNMR}\right)$ was used for the regioespecific analysis of the buriti oil and structured lipids (Vlahov, 1998). The samples were analyzed using a Burker Advanced DPX 300 NMR spectrometer (Silberstreifen, Rheinstetten, Germany). The values for ${ }^{13} \mathrm{C}$ were determined at a frequency of $75.8 \mathrm{MHz}$, with a $5 \mathrm{~mm}$ multinuclear probe operating at $30^{\circ} \mathrm{C}$. 


\subsection{Triacylglycerol composition}

The triacylglycerol composition analysis of the buriti oil and its structured lipids was performed in capillary gas chromatograph CGC Agilent 6850 Series GC System. A capillary column DB-17HT Agilent Catalog: 122-1811 (50\%-methyl-phenyl polysiloxane, $15 \mathrm{~m}$ in length $\times 0.25 \mathrm{~mm}$ in internal diameter and $0.15 \mu \mathrm{m}$ film). The conditions of analysis were carried out according to the methodology described by Antoniosi Filho et al., (1995). The analysis was carried out in duplicate and the identification of triacylglycerol groups was made by comparison of retention times.

\subsection{Tocopherols}

The determination of the levels of $\alpha, \beta, \gamma$, and $\delta$ - tocopherols was made according to the AOCS method Ce 8-89 (AOCS, 2009). The samples were diluted in hexane at a concentration of $0.1 \mathrm{~g} / \mathrm{ml}$. The samples were injected into the liquid chromatograph UHPLC. The experiment was carried out according to the methodology described by Speranza et al., (2015). The analysis was performed in triplicate.

\section{7. $\beta$-carotene}

The carotene content of the samples was determined by the spectrophotometry method (França et al., 1999). An aliquot of $0.1 \mathrm{~g}$ of oil was diluted in $25 \mathrm{ml}$ a solvent mixture of hexane and acetone P.A $(7: 3 \mathrm{v} / \mathrm{v})$ and the absorbance was read at $453 \mathrm{~nm}$. The standard curve was calibrated with $\beta$-carotene diluted to different concentrations. Results are given as $\mu \mathrm{g}$ of $\beta$-carotene per $\mathrm{g}$ of buriti oil. The analysis was performed in triplicate.

\subsection{Phenolic compounds}

The phenolic compounds were extracted with a solution of hexane and 60\% methanol (v/v). The experiment was carried out according to the methodology described by Speranza et al., (2016b). The results are given as $\mu \mathrm{g}$ of gallic acid per $\mathrm{g}$ of buriti oil (Hrnirik and Fritsche, 2004). The analysis was performed in triplicate.

\section{RESULTS AND DISCUSSION}

\subsection{Buriti oil characterization}

Prior to the interesterification reaction, the buriti oil was characterized for its fatty acid composition (Table 1). The results indicated that this oil is a rich source in oleic acid (74.2\%), followed by palmitic acid (19.8\%). Few natural oils, such as olive and patauá oils, exhibit such a high concentration
TABLE 1. Fatty acid composition (\%) of buriti oil.

\begin{tabular}{lc}
\hline Fatty acids & Buriti oil (\%) \\
\hline Palmitic acid (C16:0) & $19.81 \pm 1.14$ \\
Stearic acid (C18:0) & $1.43 \pm 0.02$ \\
Oleic acid (C18:1) & $74.21 \pm 1.04$ \\
Linoleic acid (C18:2) & $1.29 \pm 0.13$ \\
Others & 3.3 \\
\hline
\end{tabular}

All values are the mean of two replicates \pm standard deviation.

of oleic acid (Mendoza et al., 2013; Speranza et al., 2015). There is a demand by the industry for oils that have a rich oleic acid composition, since this fatty acid is less susceptible to oxidation, in addition to offering health benefits (Pacheco et al., 2008). Several oils, such as soybean and canola, are genetically modified to have a composition in oleic acid similar to the one found naturally in buriti oil (O’Brian, 2009).

The results agree with the previously published values for oleic acid, which varies between 61 and $74 \%$, and palmitic acid, which ranges from between 16 to $23 \%$ (Speranza et al., 2016a; Speranza et al., 2016b; Silva et al., 2009).

The lipid class analysis indicated that buriti oil is essentially composed of TAG $(93.4 \%)$ and still contains $6.7 \%$ of DAG. The analysis did not detect the presence of FFA or MAG in the oil. These results confirm the initial quality of this oil, an indispensable condition for the enzyme to act efficiently in the interesterification reaction. Oils with high acidity values (greater than $4 \%$ ) can cause denaturation of the enzyme, preventing its performance in an efficient and specific manner (Marangoni, 2002).

\subsection{Enzymatic interesterification}

Buriti oil was used as a substrate for enzymatic interesterification. Commercial lipase Lipozyme TL-IM, with enzymatic activity of $1653 \mathrm{U} \cdot \mathrm{g}^{-1}$ was used as reaction catalyst. This enzyme is widely used in interesterification reactions, acting on different substrates, with temperatures varying between 30 and $70{ }^{\circ} \mathrm{C}$. The interesterification was verified through lipid class analysis, the regiospecific distribution of fatty acids in the TAG and the TAG composition of the oils, as shown below.

\subsection{Lipid class}

In the enzymatic interesterification two opposite reactions occur: partial hydrolysis and re-synthesis of esters, which means that in addition to the TAG, a certain amount of partial acylglycerols will be present in the final product $(\mathrm{Xu}, 2000)$. 
The molecular exclusion chromatography analysis indicated that the TAG structure was maintained after 6,14 and $24 \mathrm{~h}$ of buriti oil interesterification (Table 2). In the reaction, the formation of a small concentration of DAG occurred, while there was no formation of MAG or FFA. These initial results indicated that the reaction conditions were appropriate for the lipase performance, and did not favor the extended hydrolysis of TAG in partial acylglycerols or FFA.

Other studies confirm the formation of a small amount of partial acylglycerols after the enzymatic interesterification using different substrates and reaction conditions. In the reaction between lard, linseed oil and fish oil catalyzed by Lipozyme RM-IM at $50{ }^{\circ} \mathrm{C}$ for $4 \mathrm{~h}$, there was a $4.1 \%$ increase in the content of partial acylglycerols and $0.2 \%$ in free fatty acid content (Wirkowska-Wojdyla et al., 2016). In the study by Brys et al., (2013) between lard and linseed oil, using Lipozyme TL-IM at temperatures of 60,70 and $80^{\circ} \mathrm{C}$ for 8 hours, there was an increase in partial acylglycerols of between 11 and $14 \%$. The content of free fatty acids varied according to the temperature used in the reaction, and the higher the temperature, the lower the FFA formation.

\subsection{Regiospecific distribution}

The regiospecific distribution analysis indicates the positions occupied by fatty acids in the TAG. The use of ${ }^{13} \mathrm{C}$ resonance was shown to be a more accurate method for making these determinations compared to the traditional method using pancreatic lipase (Speranza et al., 2016a; Vlahov, 1998).

In Figure 1A, it can be verified that the buriti oil is totally unsaturated in the sn-2 position of the TAG, and is basically composed of oleic acid, the main unsaturated fatty acid in this oil (Table 1). The sn-1,3 positions present saturated and unsaturated fatty acids in a ratio of approximately $1: 2$, respectively. In a previous study carried out with buriti oil by our working group, the regiospecific distribution was not the same, probably due to the fact that the first study was carried out with crude, non-commercial oil, with levels of free fatty acids and partial acylglycerols which were much higher than the ones in the current study (Speranza et al., 2016b).

After 6 hours of interesterification reaction, the lipase action is observed in the redistribution of fatty acids at the sn-1,3 positions of the TAG (Figure 1B). There were reductions in the contents of saturated fatty acids $(10 \%)$ and increases in unsaturated ones $(5 \%)$ in both positions. At the sn-2 position lipase did not act; the unsaturated fatty acids remained unchanged. After 14 hours of reaction (Figure 1C), the same lipase specificity can be observed; the enzyme was able to act only at the sn-1,3 positions, with an even greater reduction in the concentration of saturated fatty acids at these positions $(15 \%)$. After 24 hours of reaction (Figure 1D), the saturated fatty acids initially present at the sn- 1,3 positions in the oil were eliminated. The structured lipid produced was completely unsaturated at all three TAG positions. What probably occurred was the loss of enzyme specificity by saturated fatty acids after $14 \mathrm{~h}$ of reaction, ie the lipase was unable to re-synthesize the saturated fatty acids at the sn-1,3 positions of TAG. However, the lipase still remains capable of resynthesizing the unsaturated ones (greater specificity). These saturated fatty acids that were not resynthesized in the TAG were eliminated in the ethanol purification step performed prior to analysis (section 2.3).

Although this analysis did not detect the presence of saturated fatty acids, the results of TAG composition (section 3.5) still indicate the presence of TAG with saturated fatty acids. Differences in the type and accuracy of the analyses were most likely the cause of this difference. It is important, however, to note that both results indicate a reduction in the saturated fatty acid contents.

The lipase used in this reaction was specific for the sn-1,3 positions of TAG and for unsaturated fatty acids (oleic acid). The sn-1,3 positions of the TAG were exclusively occupied by oleic acid. In a previous work carried out by our research group with buriti oil and murumuru fat using the same enzyme, different results were observed: the enzyme was specific for the fatty acid type and showed no preference in relation to the position (Speranza et al., 2016a).

TABLE 2. Lipid classes of buriti oil and structured lipids.

\begin{tabular}{lccc}
\hline Oil & FFA + MAG & DAG & TAG \\
\hline Buriti oil & - & $6.67 \pm 0.13$ & $93.33 \pm 0.16$ \\
Structured lipid (6 h of reaction) & - & $9.30 \pm 0.10$ & $90.70 \pm 0.14$ \\
Structured lipid (14 h of reaction) & - & $9.24 \pm 0.08$ & $90.01 \pm 0.17$ \\
Structured lipid (24 h of reaction) & - & $9.19 \pm 0.01$ & $90.81 \pm 0.09$ \\
\hline
\end{tabular}

All values are the mean of two replicates \pm standard deviation.

FFA - Free fatty acids; MAG - Monoacylglycerols; DAG - Diacylglycerols; TAG - Triacylglycerols. 

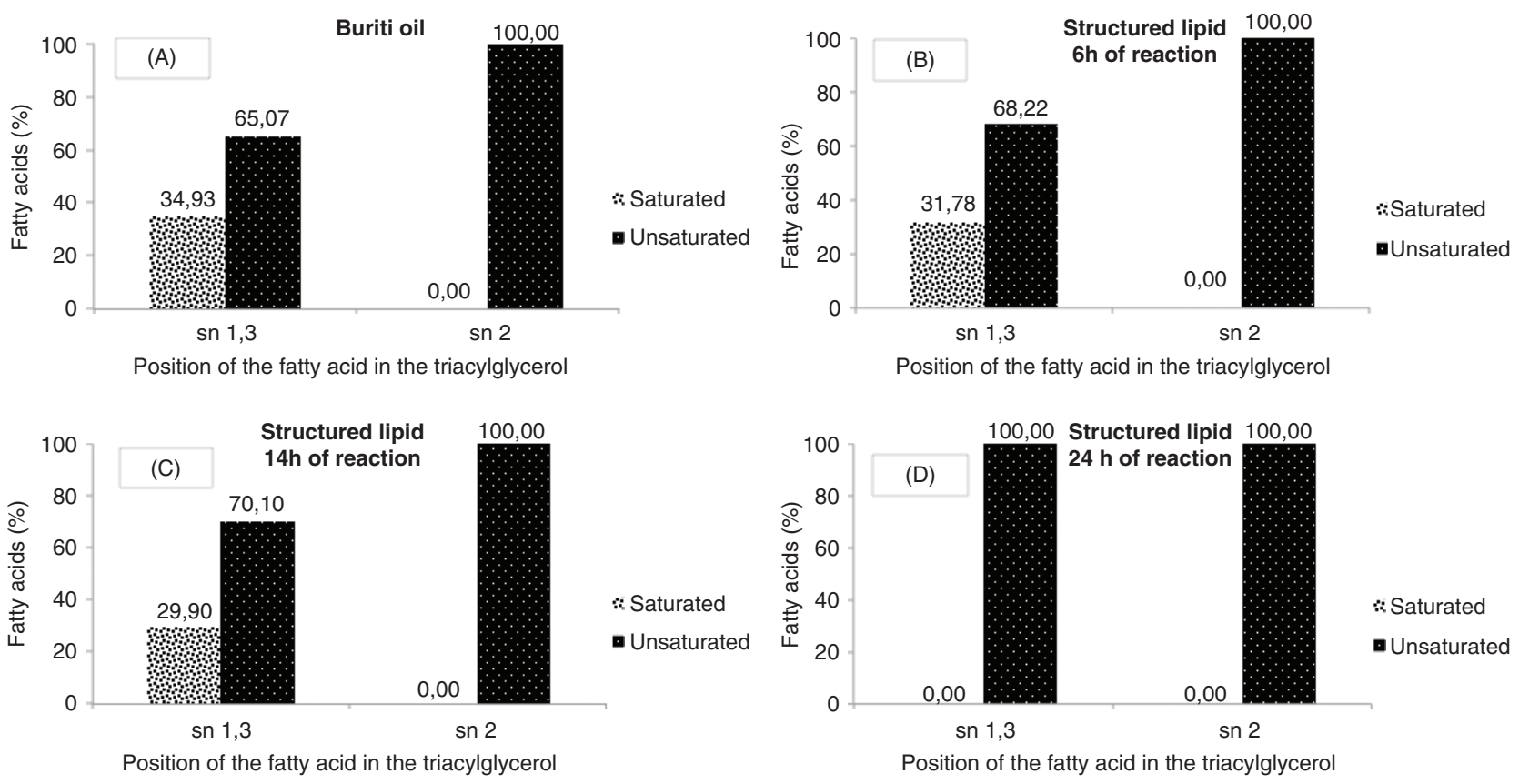

FIGURE 1. Regiospecific distribution of saturated and unsaturated fatty acids at the sn-1,3 and sn-2 positions of the triacylglycerols in buriti oil (A) and structured lipids after 6 (B), 14 (C) and 24 (D) of reaction. The values refer to a single determination.

As in this previous study, in addition to buriti oil, murumuru fat was probably present, which is rich in medium chain fatty acids, so the specificity of the enzyme was altered by changes in the structure of the substrate.

Other studies using lipase Lipozyme TL-IM also showed different results. In the study by Teichert and Akoh. (2011), where soybean oil was enriched with stearidonic acid, the enzyme was specific for palmitic acid and sn-2. In the study by Weete et al., (2008) the enzyme presented higher specificity for shorter chain fatty acids. The specificity of lipases depends largely on the structure of the substrate, on the interaction with the active site and on the reaction conditions.

\subsection{Triacylglycerol composition}

The TAG compositions of buriti oil and structured lipids are presented in Table 3 . As the concentration of partial acylglycerols and the regiospecific distribution of the structured lipids produced after $6 \mathrm{~h}$ and $14 \mathrm{~h}$ of reaction presented related results, the sample produced after $14 \mathrm{~h}$ of reaction was removed from the study.

The main types of TAGs in buriti oil are POO $(38.9 \%)$ and OOO $(32.7 \%)$. It is also possible to emphasize the presence of TAGs type PPO (9.8\%) and POL (3.9\%). Regarding structured lipids, there is a change in relation to the main types of TAG. There was a reduction in TAG type POO of $12.1 \%$ after 6 hours of reaction and $16.2 \%$ after 24 hours
TABLE 3. TAG composition of buriti oil and structured lipid produced after $6 \mathrm{~h}$ and $24 \mathrm{~h}$ of reaction.

\begin{tabular}{lccc}
\hline TAG & Buriti oil (\%) & $\begin{array}{c}\text { Structured } \\
\text { lipid (6 h) } \mathbf{( \% )}\end{array}$ & $\begin{array}{c}\text { Structured } \\
\text { lipid (24 h) (\%) }\end{array}$ \\
\hline PPP & $0.41 \pm 0.01$ & $1.01 \pm 0.02$ & $0.91 \pm 0.01$ \\
PPO & $9.76 \pm 0.07$ & $10.12 \pm 0.04$ & $8.34 \pm 0.03$ \\
PSO & $1.80 \pm 0.10$ & $1.63 \pm 0.07$ & $1.04 \pm 0.07$ \\
POO & $38.91 \pm 0.09$ & $34.17 \pm 0.04$ & $32.67 \pm 0.03$ \\
POL & $3.85 \pm 0.01$ & $4.47 \pm 0.01$ & $4.24 \pm 0.13$ \\
POL & $2.81 \pm 0.03$ & $2.86 \pm 0.03$ & $2.82 \pm 0.08$ \\
SOO & $6.14 \pm 0.07$ & $3.63 \pm 0.09$ & $4.26 \pm 0.09$ \\
OOO & $32.72 \pm 0.02$ & $36.3 \pm 0.10$ & $36.81 \pm 0.02$ \\
OOL & $2.78 \pm 0.04$ & $3.48 \pm 0.13$ & $5.44 \pm 0.08$ \\
OOL & $0.82 \pm 0.08$ & $2.33 \pm 0.08$ & $3.46 \pm 0.07$ \\
Sum & 100.0 & 100.0 & 100.0 \\
\hline Total SSS & 0.41 & 1.01 & 0.91 \\
Total SUS & 11.56 & 11.75 & 9.38 \\
Total SUU & 51.71 & 45.13 & 43.99 \\
Total UUU & 36.32 & 42.11 & 45.71 \\
\hline
\end{tabular}

All values are the mean of two replicates \pm standard deviation P: palmitic acid; S: stearic acid; O: oleic acid; L: linoleic acid; $\mathrm{L}_{\mathrm{n}}$ : linolenic acid. S: saturated and U: unsaturated.

of reaction. On the other hand, the increase in TAG type $\mathrm{OOO}$ was observed at $11 \%$ after 6 hours of reaction and $12,5 \%$ after 24 hours of reaction.

The modifications in the TAG composition of the structured lipids in relation to the buriti oil alter 
the functionality of these oils. TAGs type SUU have a melting range of 1 to $23{ }^{\circ} \mathrm{C}$, while the TAG type UUU have a melting range between 1 and $14^{\circ} \mathrm{C}$ (Rodrigues and Gioielli, 2003). The increase in the concentration of more unsaturated TAG reduces the melting range of the oil, interfering in its lubrication properties, mechanical performance, structuring and nutritional properties (O'Brien, 2009). In addition, several studies confirm the positive health effects after increasing consumption of unsaturated fatty acids (Mericli et al., 2017; Guzmán et al., 2016). The production of structured lipids from Amazonian oils, mainly composed of oleic acid, may favor interest in these raw materials which are still underutilized commercially.

Several studies in the literature indicate that a change in the TAG composition of oils and fats modifies their physicochemical properties, altering and expanding their application. Norizzah et al., (2004) studied the effect of interesterification of mixtures of palm stearin and palm kernel olein in different proportions. The results indicated that all structured lipids produced had a higher content of TAGs which were more unsaturated and with a lower melting point compared to the starting mixtures. There were significant changes in crystal morphology and in polymorphic forms. Karabulut et al., (2003) studied the interesterification process using blends of fully hydrogenated palm stearin or palm stearin with canola and cotton oils in different proportions. The process resulted in lower melting point, consistency and solid fat content for all the structured lipids produced due to the decrease in the most saturated TAG contents.

\subsection{Tocopherols}

Tocopherols are potent antioxidants of fats, and react with peroxyl radicals to prevent the formation of new free radicals and stop chain reactions. Some studies in the literature have shown that buriti oil is rich in tocopherols (Speranza et al., 2016b; Silva et al., 2009a). When the tocopherol concentration of buriti oil is compared with other oils such as soybean, known to be one of the major sources of this compound, it has been observed that the values are very close (Matthaus and Ozcan, 2014).
The results in Table 4 show that buriti oil presented the four isomers of tocopherol, and in this sample the $\beta$ isomer was predominant. In the previous work carried out by our group with buriti oil, the four isomers were also detected, with the $\alpha$ - and $\gamma$-constituents being responsible for more than $90 \%$ of the total tocopherol content (Speranza et al., 2016b). The results indicate that there is a wide variation in the tocopherol content, depending on the type of refining applied to the oil, and this variation has a great influence on the stability of the oil. Thus, other evaluations are necessary, from different oil suppliers, in order to obtain more representative results in relation to the tocopherol content of buriti oil as a function of the degree of refining applied.

After the interesterification of the oil, there is a significant loss in tocopherols, especially after 24 hours of reaction. Although interesterification occurred under mild temperature conditions $\left(40{ }^{\circ} \mathrm{C}\right)$, the loss may have been caused by the long reaction time (optimization reactions are in progress). Reshma et al., (2008) reported no influence of oil interesterification on the content of any tocopherol isomer. Although the reaction occurred at higher temperature conditions $\left(60^{\circ} \mathrm{C}\right)$, the reaction time was $6 \mathrm{~h}$.

\section{7. $\beta$-carotene}

Carotenoids are known as potent antioxidants, playing a key role in reducing the risk of cancer, cataracts, atherosclerosis and aging. Buriti oil is one of the largest known sources of carotenoids, approximately $90 \%$ of which are in the form of $\beta$-carotene (Silva et al., 2009a).

Table 5 confirms that the buriti oil used in this study has a high $\beta$-carotene concentration. In contrast to the tocopherol content, carotenoids were not influenced by interesterification. After 6 and 24 hours of reaction, the structured lipids formed contained the same concentration of $\beta$-carotene. Other studies also confirm that enzymatic interesterification does not influence the carotenoid content of the starting mixtures (Speranza et al., 2016a; Reshma et al., 2008).

Zanatta et al., (2010) evaluated the photoprotective effect in cells (fibroblasts and keratinocytes)

TABLE 4. Content of tocopherols in buriti oil and structured lipids produced after $6 \mathrm{~h}$ and $24 \mathrm{~h}$ of reaction.

\begin{tabular}{|c|c|c|c|c|c|}
\hline Sample & $\begin{array}{c}\alpha \text {-Tocopherol } \\
\left(\mathrm{mg} \cdot \mathrm{kg}^{-1}\right)\end{array}$ & $\begin{array}{c}\beta \text {-Tocopherol } \\
\left(\mathrm{mg} \cdot \mathrm{kg}^{-1}\right)\end{array}$ & $\begin{array}{c}\beta \text {-Tocopherol } \\
\left(\mathrm{mg} \cdot \mathrm{kg}^{-1}\right)\end{array}$ & $\begin{array}{c}\delta \text {-Tocopherol } \\
\left(\mathrm{mg} \cdot \mathrm{kg}^{-1}\right)\end{array}$ & $\begin{array}{c}\sum \text { Tocopherols } \\
\left(\mathrm{mg} \mathrm{kg}^{-1}\right)\end{array}$ \\
\hline Buriti oil & $15.71 \pm 0.32^{\mathrm{a}}$ & $83.62 \pm 1.82^{\mathrm{a}}$ & $5.52 \pm 0.78^{\mathrm{a}}$ & $17.4 \pm 0.35^{\mathrm{a}}$ & $122.2^{\mathrm{a}}$ \\
\hline Structured lipid ( $6 \mathrm{~h}$ of reaction) & $10.09 \pm 0.02^{\mathrm{b}}$ & $71.27 \pm 1.10^{\mathrm{b}}$ & $3.66 \pm 0.24^{\mathrm{b}}$ & $14.6 \pm 0.35^{\mathrm{b}}$ & $99.7^{\mathrm{b}}$ \\
\hline Structured lipid ( $24 \mathrm{~h}$ of reaction) & $7.44 \pm 0.19^{c}$ & $60.42 \pm 0.92^{\mathrm{c}}$ & $1.82 \pm 0.37^{\mathrm{c}}$ & $12.5 \pm 0.35^{\mathrm{b}}$ & $82.2^{\mathrm{c}}$ \\
\hline
\end{tabular}

All values are the mean of three replicates \pm standard deviation. Significant differences among the means were determined by analysis of variance and Tukey test. The same letters in the same column indicate that there was no significant difference among the samples $(\mathrm{p}>0,05)$. 
TABLE 5. Content of $\beta$-carotene in buriti oil and structured lipids produced after $6 \mathrm{~h}$ and $24 \mathrm{~h}$ of reaction.

\begin{tabular}{ll}
\hline Sample & $\beta$-carotene $\left(\mu \mathrm{g} \cdot \mathrm{g}^{-\mathbf{1}}\right)$ \\
\hline Buriti oil & $2786.83 \pm 113.09^{\mathrm{a}}$ \\
Structured lipid (6 h of reaction) & $2892.18 \pm 101.20^{\mathrm{a}}$ \\
Structured lipid (24 h of reaction) & $2665.85 \pm 98.24^{\mathrm{a}}$ \\
\hline
\end{tabular}

All values are the mean of three replicates \pm standard deviation. Significant differences among the means were determined by analysis of variance and Tukey test. The same letters in the same column indicate that there was no significant difference among the samples $(\mathrm{p}>0,05)$.

TABLE 6. Content of phenolic compounds in buriti oil and structured lipids produced after $6 \mathrm{~h}$ and $24 \mathrm{~h}$ of reaction.

\begin{tabular}{lc}
\hline Sample & $\begin{array}{c}\text { Gallic acid equivalent } \\
(\mathbf{G A E})\left(\boldsymbol{\mu g} \cdot \mathbf{g}^{-1}\right)\end{array}$ \\
\hline Buriti oil & $292.31^{\mathrm{c}} \pm 6.81$ \\
Structured lipid (6 h of reaction) & $325.72^{\mathrm{b}} \pm 9.34$ \\
Structured lipid (24 h of reaction) & $329.75^{\mathrm{b}} \pm 10.15$ \\
\hline
\end{tabular}

All values are the mean of three replicates \pm standard deviation. Significant differences among the means were determined by analysis of variance and Tukey test. The same letters in the same column indicate that there was no significant difference among the samples $(p>0,05)$.

of topical lotions formulated with different commercial surfactants and buriti oil. The results indicated that the emulsion prepared with sorbitol monoleate, hydrogenated castor oil and buriti oil was able to reduce the damage caused by UVA and UVB radiation after 60 minutes of exposure. The authors concluded that carotenoid-rich buriti oil emulsion can be used to protect cells from photooxidative damage and can be used as an adjunct to sunscreens.

\subsection{Phenolic compounds}

Phenolic compounds have a high biological potential, especially in the prevention of oxidative stress, inflammation and bacterial infections and are increasingly used in cosmetic and nutraceutical formulations. The results in Table 6 show that the buriti oil used in this study is rich in phenolic compounds. When compared to other vegetable oils, the value is close to that found in olive oil $\left(564.8-293.5 \mu \mathrm{g} \cdot \mathrm{g}^{-1}\right.$ of equivalent of gallic acid), known for its high concentration of phenolic compounds, and is higher than the walnut oil $\left(210 \mu \mathrm{g} \cdot \mathrm{g}^{-1}\right.$ of equivalent of gallic acid), almond (124 $\mu \mathrm{g} \cdot \mathrm{g}^{-1}$ of equivalent of gallic acid), hazelnut (159 $\mu \mathrm{g} \cdot \mathrm{g}^{-1}$ of equivalent of gallic acid) and Brazil nuts $\left(153 \mu \mathrm{g} \cdot \mathrm{g}^{-1}\right.$ of equivalent of gallic acid) (Kotsiou and TasioulaMargari, 2016; Miraliakbari and Shahidi, 2008).

After interesterification of the buriti oil, the structured lipids formed showed an increase in relation to phenolic compounds. These results may be due to the better solubilization of the structured lipids in the reaction medium; however, these data should be better investigated, since other studies in the literature do not confirm these results. It can be concluded that the phenolic compounds were maintained after the reaction.

\section{CONCLUSIONS}

The enzymatic interesterification of buriti oil can be an alternative to produce oils which are richer in oleic acid and with new functionalities. This study demonstrates that lipase could specifically act on buriti oil to produce structured lipids which are rich in oleic acid at the three positions of TAG, while preserving most of the naturally occurring minority compounds present in the oil.

\section{ACKNOWLEDGMENTS}

Financial support was provided by São Paulo Research Foundation (Fapesp) grant \# 2014/16530-1 and by grant \# 2015/07503-3.

\section{REFERENCES}

AOCS 2009. Official Methods and Recommended Practices of the American Oil Chemists' Society. American Oil Chemists' Society, (6th edition). Champaign.

Basso RC, Almeida AJ, Batista EAC. 2012. Liquid-liquid equilibrium of pseudoternary systems containing glycerol + ethanol + ethylic biodiesel from crambe oil (Crambe abyssinica) at $\mathrm{T} / \mathrm{K}=(298.2,318.2,338.2)$ and thermodynamic modeling. Fluid Phase Equilib. 333, 55-62. https://doi.org/ 10.1016/j.fluid.2012.07.018

Brys J, Wirkowska M, Gorska A, Ligeza EO, Brys A, Koczon P. 2013. The use of DSC and FT-IR spectroscopy for evaluation of oxidative stability of interesterified fats. $J$. Therm. Anal. Calorim. 112, 481-487. https://doi.org/10.1007/ s10973-012-2794-4

Farmani J, Safari M, Hamedi M. 2006. Application of palm olein in the production of zero-trans Iranian vanaspati through enzymatic inter-esterification. Eur. J. Lipid Sci. Technol. 108, 636-643. https://doi.org/10.1002/ejlt.200600025

França LF, Reber G, Meireles MAA, Machado NT, Brunner G. 1999. Supercritical extraction of carotenoids and lipids from buriti (Mauritia flexuosa), a fruit from the Amazon region. J. Supercrit. Fluids 14, 247-256. https://doi. org/10.1016/S0896-8446(98)00122-3

Guedes AMN, Ming CC, Ribeiro APB, Silva RC, Gioielli LA, Gonçalves LAG. 2014. Physicochemical properties of interesterified blends of fully hydrogenated Crambe abyssinica oil and soybean oil. J. Am. Oil Chem. Soc. 91, 111123. https://doi.org/10.1007/s11746-013-2360-7

Guzmán DC, Brizuela NO, Herrera MO, Peraza AV, Mejía GB. 2016. Oleic acid protects against oxidative stress exacerbated by cytarabine and doxorubicin in rat brain. Mini-Ver. Med. Chem. 16, 1491-1495. https://doi.org/10.2174/18715206156 66160504093652

Hrncirik K, Fritsche S. 2004. Comparability and reliability of different techniques for the determination of phenolic compounds in virgin olive oil. Eur. J. Lipid Sci. Technol. 8, 540-549. https://doi.org/10.1002/ejlt.200400942

Karabulut I, Kayahan M, Yaprak S. 2003. Determination of changes in some physical and chemical properties of soybean oil during hydrogenation. Food Chem. 81, 453-456. https://doi.org/10.1016/S0308-8146(02)00397-7 
Kotsiou K, Tasioula-Margari M. 2016. Monitoring the phenolic compounds of Greek extra-virgin olive oils during storage. Food Chem. 200, 255-262. https://doi.org/10.1016/j. foodchem.2015.12.090

Marangoni AG. 2002. In: Kuo TM, Gardner HW (ed) Lipases: Structure, Function, and Properties. Lipid Biotechnology, Marcel Dekker, New York. https://doi.org/10.1201/978020 3908198.pt3

Matthausa B, Özcan MM. 2014. Fatty acid and tocopherol contents of several soybean oils. Nat Prod Res: Formerly Natural Product Letters. 28, 589-592. https://doi.org/10.10 80/14786419.2014.883396

Mendoza MF, Gordillo CM, Expósito JM, Casas JS, Cano MM, Vertedor DM, Baltasar MNF. 2013. Chemical composition of virgin olive oils according to the ripening in olives. Food Chem. 141, 2575-2581. https://doi.org/10.1016/j. foodchem.2013.05.074

Mericli F, Becer E, Kabadayı H, Ozek T, Vatansever S. 2017. Fatty acid composition and anticancer activity in colon carcinoma cell lines of Prunus dulcis seed oil. Pharm Biol. 55, 1239-1248. https://doi.org/10.1080/13880209.2017.1296003

Miraliakbari H, Shahidi F. 2008. Antioxidant activity of minor components of tree nut oils. Food Chem. 111, 421-427. https://doi.org/10.1016/j.foodchem.2008.04.008

Morais LRB, Gutjahr E. 2011. Chemistry of vegetable oils. Valorization of Amazonian Biodiversity. Agência de Cooperação Técnica Alemã (GTZ), Alemanha.

Norizzah AR, Chong CL, Cheow CS, Zaliha O. 2004. Effects of chemical interesterification on physicochemical properties of palm stearin and palm kernel olein blends. Food Chem. 86, 229-235. https://doi.org/10.1016/j.foodchem.2003.09.030

O'Brien RD. 2009. Fats and Oils: formulating and processing for applications. $3^{\text {rd }}$ edn. CRC Press, United States of America.

Pacheco YM, López S, Bermúdez B, Abia R, Villar J, Muriana FJ. 2008. A meal rich in oleic acid beneficially modulates postprandial sICAM-1 in and SVCAM-1 in normotensive and hypertensive hypertriglyceridemic subjects. J. Nutr. Biochem. 19, 200-205. https://doi.org/10.1016/j.jnutbio.2007.03.002

Reshma MV, Saritha SS, Balachandran C, Arumughan. 2008. Lipase catalyzed interesterification of palm stearin and rice bran oil blends for preparation of zero trans shortening with bioactive phytochemicals. Bioresource Technol.99, 5011-5019. https://doi.org/10.1016/j.biortech.2007.09.009

Rodrigues JN, Gioielli LA. 2003. Chemical interesterification of milkfat and milk fat-corn oil blends. Food Res. Int. 36, 149-159. https://doi.org/10.1016/S0963-9969(02)00130-8

Rodriguez-Amaya DB, Kimura M, Amaya-Fárfan J. 2008. Fontes Brasileiras de Carotenóides. Brasília: Ministério de Meio Ambiente/Secretaria de Biodiversidade e Floresta, Brasilia.

Silva RC, Cotting LN, Poltronieri TP, Balcão VM, Almeida DB, Goncalves LAG, Grimaldi R, Gioiell LA. 2009a. The effects of enzymatic interesterification on the physical-chemical properties of blends of lard and soybean oil.
LWT - Food Science Technol. 42, 1275-1282. https://doi. org/10.1016/j.lwt.2009.02.015

Siqueira EP, Andrade AA, de Souza-Fagundes EM, Ramos JP, Kohlhoff M, Nunes YR, Cota BB. 2014. In vitro antibacterial action on methicillin-susceptible (MSSA) and methicillin- resistant (MRSA) Staphylococcus aureus and antitumor potential of Mauritia flexuosa L. J. Med. Plants Res. 8, 1408-17.

Speranza P, Macedo GA 2012. Lipase-mediated production of specific lipids with improved biological and physicochemical properties. Process Biochem. 47, 1699-1706. https://doi. org/10.1016/j.procbio.2012.07.006

Speranza P, Ribeiro APB, Macedo GA. 2015. Lipase catalyzed interesterification of Amazonian patauá oil and palm stearin for preparation of specific-structured oils. $J$. Food Sci. Technol. 52, 8268-8275. https://doi.org/10.1007/ s13197-015-1943-8

Speranza P, Ribeiro APB, Macedo GA. 2016a. Application of lipases to regiospecific interesterification of exotic oils from an Amazonian area. J. Biotechnol. 218, 13-20. https:// doi.org/10.1016/j.jbiotec.2015.11.025

Speranza P, Falcão AO, Macedo JA, Silva LHM, Rodrigues AMC, Macedo GA. 2016b. Amazonian Buriti oil: chemical characterization and antioxidant potential. Grasas Aceites 67, e135. https://doi.org/10.3989/gya.0622152

Teichert SA, Akoh CC 2011. Stearidonic acid soybean oil enriched with palmitic acid at the sn-2 position by enzymatic interesterification for use as human milk fat analogues. J. Agric. Food Chem. 59, 5692-5701. https://doi.org/10.1021/ jf $200336 \mathrm{t}$

Vlahov G. 1998. Regiospecific analysis of natural mixtures of triglycerides using quantitative ${ }^{13} \mathrm{C}$ nuclear magnetic resonance of acyl chain carbonyl carbons. Magn. Reson Chem. 36, 359-362. https://doi.org/10.1002/(sici)1097-458x (199805)36:5<359::aid-omr274>3.3.co;2-q

Weete JD, Lai O-M, Akoh CC. 2008. In: Akoh CC, Min DB (ed) Microbial lipases. Food Lipids: Chemistry, Nutrition and Biotechnology, $3^{\text {rd }}$ edn. CRC Press, New York.

Wirkowska-Wojdyla M, Brys J, Górska A, Ostrowska-Ligeza E. 2016. Effect of enzymatic interesterification on physiochemical and thermal properties of fat used in cookies. LWT - Food Science Technol. 74, 99-105. https://doi.org/ 10.1016/j.lwt.2016.07.040

Xu X. 2000. Production of specific-structured triacylglycerols by lipase-catalyzed reactions: A review. Eur. J. Lipid Sci Technol. 102, 287-303. https://doi.org/10.1002/(SICI)14389312(200004)102:4<287::AID-EJLT287>3.0.CO;2-Q

Zanatta CF, Ugartondo V, Mitjans M, Rocha-Filho PA, Vinardell MP. 2010. Photoprotective potential of emulsions formulated with Buriti oil (Mauritia flexuosa) against UV irradiation on keratinocytes and fibroblasts cell lines. Food Chem. Toxicol. 48, 70-75. https://doi.org/10.1016/j. fct.2009.09.017 